\title{
Introduction: A New History of Russian Science
}

\section{Alexei Kojevnikov}

Department of History, University of Georgia, Athens, Georgia.

Institute for the History of Science and Technology of the Academy of Sciences, Moscow

Like almost everything in the Soviet Union, the discipline of history of science and technology altered dramatically during the social upheaval of Gorbachev's perestroika, in some ways that were predictable, and in other ways that were not. One new direction of research that has since grown into a bourgeoning field - the social history of Russian and Soviet science - is represented by the articles in this volume. This short introduction cannot substitute for a real historiographical study, which will probably appear in due course (see also Gerovitch 1996, Gerovitch 1998, Graham 1993). This is rather a personal memoir about the origin and motivations behind the approach; as incomplete as a participant's memoir can be, but with some benefits of retrospective hindsight. Ten years ago, at a time of great fluidity in minds and intellectual agendas, many developments were driven primarily by intuition and the sheer momentum of Zeitgeist; now, as things have become somewhat settled, there is time for more reflection.

The change is particularly striking when contrasted with the status quo ante. Someone like myself, coming to the field as a graduate student in Moscow around the mid-1980s, entered an intellectual milieu dominated by the towering figures of Karl Popper, Imre Lakatos, and Thomas Kuhn, and was encouraged to pursue the history of science along the lines favored by that generation of philosophers. A historical thesis did not have to be philosophically oriented, but quite technical, focused primarily on the development of scientific ideas and concepts, preferably international in scope, and with a topic defined according to the recognized divisions within scientific disciplines. Among the reasons contributing to the popularity of this genre, not the least important was that such scholarship was perceived as "apolitical" in the late Soviet mindset, meaning that it allowed historians to distance themselves from the moribund official political discourse without explicitly contradicting it. This privilege would have been much harder to achieve dealing with topics related to the history of Russian/Soviet science, or, in general, to the social context of science. Such studies required some accommodation to the official ideology and/or the use of Aesopian language, and increasingly often were relegated to ceremonial addresses presented by some official persona on an occasion of an anniversary or some event.

The history of science as practiced in today's Russia, on the contrary, demonstrates a radical turn from published sources to archival digging, from intellectual to social history, and from international to Russian topics. Some of these trends have even 
gone too far, to my taste. The excesses (not represented in this selection) include numerous publications reduced to a copy of an archival document with little commentary, or articles in academic journals resembling exercises in anticommunist political propaganda. The large majority of publications in the history of science now deal with national developments and events, a trend by no means unique to Russia. This imbalance, however, is more in proportion than in the content of research, which still remains less narrowly parochial than it is currently common among historians of, say, British or American science. Articles in this issue all focus on science in Russia and the Soviet Union, but as the reader will notice, they also include comparative perspectives and look for connections with developments in other countries.

The dramatic reorientation in historians' research agendas came about in the course of just a few years and coincided with the general political and social revolution we experienced at the time. That the two developments were linked is clear in retrospect, and such an explanation can easily be constructed. Yet, ironically, as I recall my personal drift from the history of quantum electrodynamics to the history of Stalinist physics, "big" events recede to the background, while small and accidental encounters magnify in proportion. Events perceived at the time to be efficient causes (in the Aristotelian sense), were, for example, being allowed to look at a pile of scientific correspondence preserved in a family archive; or a realization that prior to the Stalinist purges, the best physics institute was not in Leningrad or Moscow, but in Khar'kov, Ukraine; or a vague hint in a book that an entire generation of Soviet scientists were brought up to maturity and fame without any need for a Ph.D. or other academic degree, while for a time professors were not allowed to teach lectures, only seminars. These "discoveries" were enough to inspire curiosity, and by 1987 something was definitely in the air in the general political climate. Nobody knew yet whether vague indications of political liberalization should be taken seriously, yet I remember thinking - naively, of course - that more than fifty years after the events, one should be able to look at one's own history more "objectively," beyond the boringly censored official version, regardless of whether or not the general liberalization came.

Other colleagues, including Olga Elina, Kirill Rossiianov, and Irina Sirotkina, developed similar interests, and by year's end there were enough of us to start an informal seminar at the Institute for History of Science and Technology. The books reviewed and discussed there were not the ones normally published in the Soviet Union, but illegal samizdat or foreign-published tamizdat. Western literature on Soviet history was still not easily accessible at the time: even politically innocuous volumes such as the issue of Isis with Douglas Weiner's paper on the history of Russian nature conservation in the 1920s, ended up in the library's special collection, so that scholars had to ask for administrative permission in order to consult it. As it turned out, however, almost everybody kept in one's home library a book or two of that kind, which could be discussed and exchanged at the seminar. By that time liberalization from above had definitely started, and a high party commission was issuing occasional 
announcements on the rehabilitation of some top victims of Stalin's purges, ending with the most important line: "the commission continues to work." In spring 1988 the barriers were broken from below, and stories about Stalinist crimes began to fill the pages of virtually every daily, weekly, and monthly periodical.

While historians of science in Moscow were still learning, in Leningrad, where things were brewing in a similar way, Daniel Alexandrov and Nikolai Krementsov took the bolder step of going public and submitted to VIET (Voprosy Istorii Yestestvoznaniya i Tekhniki), the country's main journal on science studies, their paper "A guide to the unknown land: A preliminary sketch of the social history of Soviet science" (Aleksandrov and Krementsov 1989). The intensity of our informal contacts was helped enormously by the concentration of the majority of the country's historians of science in one institute, with two branches in Moscow and Leningrad. At a conference in May 1989 a small community was born - largely a generational phenomenon - with the core group consisting of recent or soon-to-be Ph.D. graduates eager to carve a new research field for themselves - the social history of Soviet science - without guidance from senior colleagues. Subsequent annual conferences and continuous discussions stimulated the best brainstorming mutual learning I have experienced in my scholarly life. ${ }^{1}$

Any hope that new freedom would make history less politicized, however, had to be abandoned. If in nineteenth-century Russia journalists waged political battles under the guise of literary criticism, during Gorbachev's perestroika they used history for the same purpose. For several years, the largest portion of daily news consisted of revelations about the Stalin era, but the meaning of the message, of course, was contemporary rather than historical: the revenge of the past, more than anything else, eroded and eventually destroyed the Communist Party rule. Academics were also carried away by these currents, producing in the history of science a stream of writings under the general motto "terrorized science" (repressirovannaya nauka), which depicted Soviet science as a victim of ideology, political control, and state violence. From the social history perspective, such a vision was too narrow. We did not look at science and scientists as mere victims, but essential and active participants in the Soviet polity. As much as one hoped to contribute to the ongoing democratic revolution, replacing communist propaganda stereotypes with equally one-sided anticommunist ones did not seem to be the right way to do it (Kozhevnikov [Kojevnikov] 1991).

Further steps, such as looking at the deeper relationship between knowledge and power and analyzing scientific knowledge in its social context met a different kind of resistance. For some more experienced colleagues this approach seemed too close to the familiar Marxist dictum that sciences, including the most abstract ones, are grounded in social practices. They were right: my obligatory college-level training in

\footnotetext{
${ }^{1}$ For reviews of the conferences, see Aleksandrov and Krementsov 1990; Kozhevnikov [Kojevnikov] 1991; Sirotkina and Elina 1992.
} 
Marxist philosophy became very useful as an introduction to the more recent Anglophone literature on social constructivism. The early push toward analyzing social aspects of science came during the first half of the twentieth century from the Marxist tradition, and some Marxists also extended the social constructivist argument to scientific knowledge. The latter effort, however, remained controversial and was later abandoned by Soviet authors on the grounds of being too crude and infringing upon scientific realism. ${ }^{2}$ Ironically, as the Soviet intelligentsia was rejecting the country's official ideology, some elements of this ideology made a surprise comeback from the West, where these ideas had in the meantime developed further away - but not beyond recognition - from their Marxist roots.

Hardly anything can contribute as much to the professional development of a historian as living through an actual revolution. Our generation had the rare opportunity to feel the pulse of history in August 1991, when events were unpredictable, decisions spontaneous and often unexplainable, but their effects tremendously significant and longlasting. In the narrower discipline of the history of science and technology, too, there was a strong urge for serious but not exactly clearly defined changes. It so happened that the social history of Russian and Soviet science became one of the new favorites that autumn. This development came about more like a change of mood rather than by way of institutional changes, although in October 1991 the Institute's academic council discussed a program of research in the field, which suddenly came into prominence. Some time later, the journal VIET established a heading for the publication of articles on the topic.

With this growth in size and popularity, however, came other changes: more diversity and, to some degree, the loss of initial focus. The formerly close-knit group of students matured and embarked on separate - sometimes international - careers, discovering the world and adopting more cosmopolitan, comparative attitudes. Although "social history" prevailed in name, approaches formerly defined as "terrorized science" continued to thrive even under the new heading, at least for the time being. In a topic dominated so long by powerful propaganda machines, the liberation of an academic research field from the Cold War mentality did not come easily and has yet to be completed. Old Soviet stereotypes are less of a problem now, but a resurgence of some old American stereotypes has partly filled the ideological vacuum. The problem is perhaps even more acute when it comes to the literature on Soviet science available in the English language, with its overwhelming fixation on Lysenko, and, to a lesser degree, the Sputnik shock and atomic spy stories. Outside the area of a few intensively covered topics, the rich history of Russian and Soviet science is still to a large degree unexplored.

The papers in this issue represent a wide range of approaches, but they all venture into uncharted territories. Dimitri Bayuk's article on Vladimir Odoevskiy's musical inventions opens up the problem of Russian romanticism and science. Unique and

\footnotetext{
${ }^{2}$ For a classic (and also the most controversial) example of the Marxist social constructivist argument applied to scientific knowledge, see Bogdanov [1918] 1990.
} 
idiosyncratic as the case might look at first glance, it is actually a very characteristic illustration of the position of science in mid-nineteenth century Russian culture, when the latter was still dominated by the arts, nationalism, and romanticism, before the public turned to an overly enthusiastic embrace of the positive sciences in the 1860s. Olga Elina's article challenges one of the most common historiographic assumptions, namely the tendency to oppose the Soviet developments to the prerevolutionary ones by taking 1917 as the ultimate break. She looks at modernization in agriculture and agricultural science as a continuing process, with trends established in the late imperial era and upheld, in a somewhat modified and strengthened form, under the Bolsheviks. Undermining yet another, even stronger historiographic stereotype, she shows that the agency initiating the drive toward modernization was the public and civil society, rather than the state, in an unexpected contrast to analogous developments in the United States.

The case discussed in my article also crosses the revolutionary divide, but by focusing on industrially and militarily important sciences. Except for military history per se, World War I was until recently a topic rarely studied by Russian historians, especially with regard to science. The study, however, reveals that the experience of the on-going war pushed Russian academics toward embracing a new concept of science, which was later labeled "the Soviet model of research" in the USSR and "big science" in the US. Kirill Rossiianov's article provides a shocking account of experiments on crossbreeding humans with anthropoid apes. In order not to spoil the reader's pleasure of learning about the results and the conclusions, I will not summarize the paper here, except for drawing attention to the author's comment that images of apes in scientists' and the public's perception were distorted mirrors of what human actors thought of themselves in their own societies and locations, as they traveled from revolutionary Russia to Western Europe, and to colonial Africa. The case is destined to spark controversy, since the events described in it touch upon or break down our most important taboos related to species, race, gender, family, religion, and social hierarchy.

The paper by Konstantin Ivanov deals with another virtually unexplored period, the Soviet Union after Stalin. Much of what we know about Soviet science comes from the studies of the early revolutionary and Stalinist periods, and is often by extension considered true also for the late Soviet Union. The paper shows how wrong this common assumption is, and how deep changes - in some cases reversals - of the basic vision of science and technology were instituted in a somewhat conservative fashion, by maintaining the façade of reforms ostensibly aimed at improving, but not subverting, the continuing ideological orthodoxy. The importance of this argument is not restricted to the sciences, since similar post-Stalinist changes were taking place in other areas as well, but a broad interpretation of late Soviet history still remains to be written. Slava Gerovitch analyzes the post-Stalin transition in the case of the conceptual polemics between the Pavlov doctrine and cybernetics, at the intersection of technology, mathematical, computer, and 
behavioral sciences. Cybernetics, more than any other general scientific concept, captured the imagination of an entire generation of Soviet scientists in the 1960s. At the base of this transition, Gerovitch uncovers a fundamental shift in the basic metaphors regarding the relationship between machine and organism, and explores the complex interplay of science, ideology, and rhetoric in the debate.

The papers in this issue represent of course only a small fraction of the research of the last decade that is changing the way we see the development of science in Russia. Despite - or maybe because of - increased attention, the story in its complexity has only started to unfold, and there is a growing awareness of how many questions and topics are still waiting for an investigation. Some important methodological problems also remain unresolved; probably the biggest of them is the integration of Russian developments into the general history of science and technology. This same problem presents a challenge to social histories of science in other countries and communities, which are becoming too narrowly localized. An additional complication in the Russian case comes from the ubiquity of a pseudo-solution, the old and non-dying habit of thinking in terms of polarities and the contrasts between things Russian and "Western," the favorite discourse of nationalists and imperialists on each side. The case of Vladimir Odoyevskiy described in this issue is a good illustration of the problems associated with thinking in such categories. In addition, features usually constructed as "Western" for the purposes of contrast start breaking down immediately once one looks at the differences among various countries in the supposedly uniform West. Instead of sweeping but primitive generalizations, a real comparative history has to be developed. We are not there yet, but hopefully, the articles in this issue will help advance towards this goal.

\section{References}

Aleksandrov [Alexandrov], D. A. and N. L. Krementsov. 1989. "Opyt putevoditelya po neizvedannoy zemle: predvaritel'nyy ocherk sotsial'noy istorii sovetskoy nauki (1917-1950-e gody)." Voprosy Istorii Yestestvoznaniya i Tekhniki 4:67-87.

Aleksandrov, D. A. and N. L. Krementsov. 1990. "Sotsiokul'turnye aspekty razvitiya sovetskoy nauki v 1920-1930 gg." Voprosy Istorii Yestestvoznaniya i Tekhniki 1:166-168.

Bogdanov, A. A. [1918] 1990. "Nauka i rabochiy klass." Reprinted in A. A. Bogdanov. Voprosy sotsializma: Raboty raznykh let, 360-376. Moscow: Izdatel'stvo politicheskoy literatury.

Gerovitch, Slava. 1996. "Perestroika of the History of Technology and Science in the USSR: Changes in the Discourse." Technology and Culture 37(1):102-134.

Gerovitch, Slava. 1998. "Writing History in the Present Tense: Cold War-Era Discursive Strategies of Soviet Historians of Science and Technology." In Universities and Empire: Money and Politics in the Social Sciences During the Cold War, edited by Christopher Simpson, 189-228. New York: New Press.

Graham, Loren R. 1993. Science in Russia and the Soviet Union: A Short History. Chap. 7: "Soviet Attitudes toward the Social and Historical Study of Science." Cambridge: Cambridge University Press.

Kozhevnikov [Kojevnikov], A. B. 1991. "Vtoraya konferentsiya po sotsial'noy istorii sovetskoy nauki." Voprosy Istorii Yestestvoznaniya i Tekhniki 4:154-155.

Sirotkina, I. E. and O. Yu. Elina. 1992. "Chetvërtaya konferentsiya po sotsial'noy istorii nauki.” Voprosy Istorii Yestestvoznaniya i Tekhniki 3:163-165. 